\title{
Tendencies and Relations of Defense Spending and Economic Growth in the EU Countries
}

\author{
Gitana Dudzeviciute ${ }^{1,2}$, Kestutis Peleckis ${ }^{2}$, Valentina Peleckiene ${ }^{2}$ \\ ${ }^{1}$ The General Jonas Zemaitis Military Academy of Lithuania \\ Silo st. $5^{a}$, LT-10322 Vilnius, Lithuania \\ E-mail.gitana.dudzeviciute@vgtu.lt \\ ${ }^{2}$ Vilnius Gediminas Technical University \\ Sauletekio av. 11, LT-10223 Vilnius, Lithuania \\ E-mail.gitana.dudzeviciute@vgtu.lt,kestutis.peleckis@vgtu.lt,valentina.peleckiene@vgtu.lt \\ cross $^{\text {ref }}$ http://dx.doi.org/10.5755/j01.ee.27.3.15395
}

European countries are surrounded by growing conflicts and security threats. For every country it is necessary to ensure internal and external security. Defense should be seen as preventative spending as well as like an insurance policy. In terms of that, many policy makers have to decide how much money should be spent on defense. This paper investigates the tendencies and relationships of defense spending and economic growth in the European Union (EU) countries taking into consideration the level of countries' economic development over the period of 2004-2013. The authors have done this by considering a number of descriptive statistical indicators and applying Granger testing. Based on the real gross domestic product (GDP) per capita, the European Union countries have been classified into five categories. The association between defense spending and economic growth has been estimated. On the basis of causality testing, the prevailing causality direction is from defense spending to economic growth in the group of countries of a very high level of economic development. However, in the group of countries of lower or mid-level of economic development the causality runs from economic growth to defense spending. For the remaining group of countries, no causal relationship has been detected between these two variables. The paper is concerned with defense spending and economic growth only. The authors have not considered all the other factors. That is the major limitation of this paper. Despite of this, the research highlights the key trends and relationships, which should be of particular interest to policy makers. However, every country is unique, and the economic growth or decline do not imply spontaneous change in defense expenditure. Prospective threats may be the most important factor for the expansion of defense spending.

Keywords: Real Gross Domestic Product, Economic Growth, Defense Spending, Granger Causality, European Union.

\section{Introduction}

Over the last decade, defense spending has been cut across many of the EU countries. The budgetary motivations for this have been related to less strategic, geopolitical and terrorism related implications (Lilico, 2013). Defense spending has been decreasing an average of 10 percent in the EU countries over the last six years (Eurostat, 2012 b). Recently, growing security threats and conflicts in the European Union countries, Ukraine, Egypt, Libya, Syria, Israel-Palestine have prompted debates among policy makers and scholars regarding spending for defense in the context of economic growth. According to Lilico (2013), spending for defense can help to promote long-term economic growth. Defense sector should be examined as a combination of other activities, such as research and development, manufacturing, human resources management and so on. Defense could be as preventative spending as well as it could be thought of as an insurance policy. In case some foreign power starts becoming aggressive, the country must have available resources to reduce the impact of that aggression (Lilico, 2013).

The review of the recent research (Alptekin, Levine, 2012; Anwar et al., 2012; Tiwari, Shahbaz, 2013; Khalid, Mustapha, 2014; Duella, 2014; Ave et al., 2014; Mosikari, Matiwa, 2014; Malizard, 2014) has revealed inconclusive results. It may be noticed that in academic context defense spending - economic growth nexus has been analyzed from different theoretical aspects. Theoretical insights have revealed unidirectional, bidirectional or non-existent defense spending - economic growth relationships (Harley \& Sandler, 2011; Feridun et al., 2011; Alptekin \& Levine, 2012; Danek, 2013; Chairil et al., 2013; Khalid \& Mustapha, 2014; Duella, 2014; Topcu \& Aras, 2015). Moreover, the impact of defense spending on economic growth has been either positive or negative. Positive effect has been demonstrated referring to the fact that defense spending leads to formation of human capital, if the part of this expenditure is used for education, training; defense spending accelerates economic growth if some of it is used for the creation of socio-economic infrastructure (Pradhan, 
2010). It has been acknowledged, that many defense projects stimulate the development of technologies that eventually have non-military appplication (Lilico, 2013). Spending for defense can improve productivity and generate welfare, if the part of spending is used for revamping the economy during crisis like terrorist attacks and earthquakes (Pradhan, 2010).

Defense has protected property rights and trade through sea and air. That has macroeconomic implications, because if property rights and trade are not secure, businesses will not invest (Lilico, 2013). The research of the EU countries has revealed positive impact of defense spending on GDP. As spending for defense increases by Euro 100 million, GDP goes up by Euro 150 million (Savolskis, 2014).

To conclude, in terms of economic growth process through increased utilization of capital stock, promoting employment, profits and investment, the effect of defense spending turns out to be positive.

Negative impact on economic growth could be seen from the allocation of large government expenditure towards defense sector in the budget. It would leave other economic sectors with less financial resources. In this case, defense spending can hinder economic growth through the crowding-out of investment as well as civilian budgetary outlays such as health and infrastructure expenditure (Feridun et al., 2011).

From the growth perspectives, when economy grows, the government has more possibilities to allocate financial resources for security. However, it may be more a political decision. According to Hartley and Sandler (2011), defense spending has to be evaluated not only in the economic context, but also with respect to its political implications.

Object of the research: the relationship between defense spending and economic growth in the EU.

Aim of the research: to investigate empirically the causal relationship between defense spending and economic growth in the European Union countries using annual data of 2004-2013.

The direction of causality has significant policy implication. On the one hand, in the case of unidirectional causality running from defense spending to economic growth, reducing defense spending could reduce economic growth. On the other hand, in the case of unidirectional causality from economic growth to defense expenditure, conservation policies may be implemented with little or no effects on economic growth. When causality does not exist, it means that neither conservative, nor expansive policies regarding defense spending have any impact on economic growth.

Limitations of the research: the paper is bounded with defense spending and economic growth only. All other factors are not considered here. In reality, defense spending and economic growth may be affected by many other variables which are interrelated among themselves and affect others.

The second limitation has been related to analyzed period. Analyzed period of nine years might be too short to establish causal relationship between defense spending and economic growth. The authors have analyzed the data from 2004 to 2013. We consider this to be the appropriate period for analysis due to the European Union's rapid enlargement. In 2004, ten countries joined the European Union. On the other hand, the data of all the European Union countries have been available since 2004.

Despite the limitations, we believe that this research highlights the key trends and relationships.

The paper is organized as follows. Section 2 reviews previous studies on the relationship between defense spending and economic growth and the research methodology. The studies are summarized and the main insights are provided. Section 3 analyses the main trends and estimates interrelationship as well as causal relationship between defense spending and economic growth for five groups of the EU countries. Section 4 provides conclusions, summarizing the main trends observed.

The research methods applied include systemic analysis of scientific literature, statistical, time series cross correlation and comparative analysis and causality estimation.

\section{Theoretical Insights Review and Methodology Overview of Recent Research}

The interest has always been to examining the defense spending - economic growth nexus in a range of countries all over the world (Keller et al., 2008; Atesoglu, 2009; Yang et al., 2011; Feridun et al., 2011; Alptekin \& Levine, 2012; Danek, 2013; Chairil el al., 2013; Aye et al. 2014; Duella, 2014; Dunne \& Tian, 2015; Malizard, 2015; Alexander, 2015). The pioneering studies by Benoit (1973) have shown the relevance of examination the defense spending - economic growth nexus (Yang et al., 2011). According to Alexander (2015), the issue of guns and butter has been one of the fundamental economic questions. There is no consensus about the existence of causal relationship between the variables, its nature and direction, due to the level of socio-economic development of the countries involved, the period analyzed as well as the methodology employed. As pointed out above, unidirectional, bidirectional and no causality have been reported by researchers. In this section, the authors have done an overview of recent research regarding defense spending economic growth nexus across different countries.

Keynesian macroeconomic theory has assumed that increased government expenditure tends to lead to rapid economic growth. While Wagnerian theory has presented the opposite view, that the economy growth causes more government expenditure (Bataineh 2012).

Topcu and Aras (2015) have examined the long-run causal ordering between the defense spending and economic growth. They have acknowledged different results across the EU countries. The insights have revealed a split between the strongest countries, where bidirectional as well as unidirectional causality running from defense spending to economic growth has been detected compared to the rest of counties, where either no causal relationship has been found or the direction of causality has been from economic growth to defense spending.

The investigation of long-run relationship between defense spending and economic growth for 92 countries have pointed, that defense spending has a significantly negative relationship with economic growth for the 23 countries with low incomes and no significant relationship 
exists for the remaining 69 countries with high initial incomes (Yang et al. 2011).

The research of Mylonidis (2008), Kollias, Paleologou (2010), Dunne and Nikolaidou (2012) has revealed this relationship across the EU15 countries. The findings of these studies have varied due to the period analysed as well as methodology employed. Mylonidis (2008) has suggested that defense spending has an overall negative impact on economic growth in the EU15. Moreover, Kollias and Paleologou (2010) have focused on the relationships among economic growth, investment and defense spending in the EU15 for the long-run period. The research has showed that economic growth has a positive impact on defense spending and investment as well. The research done by Dunne and Nikolaidou (2012) has revealed that defense expenditure has not accelerated economic growth across the EU15 countries.

The causation relationship between defense spending and economic growth in developing countries was subject to intense debate in recent years. The study of Duella (2014) examined the causal relationship in Algeria for the period of 1980-2010. The investigation showed the existence of unidirectional causality between economic growth and defense spending.

The examination of defense spending - economic growth nexus was conducted by Mosikari and Matiwa (2014) in South Africa in a period of 1988-2012. The causal analysis revealed that military expenditure was Granger cause of economic growth at 5 percent of significance level.

Shahbaz et al. (2013) focused on examination of causal relationship between defense spending and economic growth for Pakistan. Empirical evidence has suggested that an increase in defense spending reduces the pace of economic growth. Finally, unidirectional causality running from defense spending to economic growth has been found.

Farzanegan (2014) investigated the response of the Iranian economy to shocks in its military budget from 1959 to 2007. The findings have showed unidirectional causality running from the defense spending to the economic growth rate. Hirnissa and Baharom (2009) focused on five Asian countries. They examined causal effect and long - run relationships between defense spending and economic growth from the year of 1965 to 2006 . The results showed that Indonesia, Thailand and Singapore exhibited long run relationship between military expenditure and economic growth. For Singapore, the causality was bidirectional, for Indonesia and Thailand it was unidirectional running from military expenditure to economic growth; and for the remaining countries, such as Malaysia and Philippines, no significant relationship was detected. Later the same Asian countries were observed by Pradhan (2010) over the period of 1988-2007. The research has suggested the presence of unidirectional causality from economic growth to defense spending in Thailand, Indonesia, Malaysia and Singapore. It also finds the feedback between defense spending and economic growth in Philippines at the individual level. The implication of this investigation has been that neither defense spending nor economic growth can be considered as exogenously determined.

The study of Rashid and Arif (2012) attempted to reexamine the causal relationship between the two variables in 14 developing countries for the period of 1981-2006. Results reported in the paper suggest that defense expenditure is an exogenous variable and this variable influences economic growth in these countries.

Taking into consideration empirical insights from investigations, it could be concluded that in many cases the defense spending - economic growth nexus has been detected, but the practices in a range of countries all over the world lead to different results due to the level of socioeconomic development of the countries involved, the period analyzed as well as the methodology applied.

\section{Research Methodology}

This research has been guided by the estimation of defense spending - economic growth nexus in the European Union countries. The authors have referred to Keynesian macroeconomic approach as well as Wagnerian theory (Bataineh 2012) and Granger causality testing, which is prevailing method in recent similar research (Hirnissa \& Baharom, 2009; Pradhan, 2010; Feridun et al., 2011; Dimitraki \& Ali, 2013; Shahbaz et al., 2013; Khalid \& Mustapha, 2014; Duella, 2014; Mosikari \& Matiwa, 2014; Dunne \& Tian, 2015; Topcu \& Aras, 2015). The ratios of defense expenditure as a percentage of GDP and GDP per capita are used. Granger test has assessed the running causality and the direction of relationship between defense spending and economic growth. Granger causality test requires estimating the following two regression equations (Shahbaz et al., 2013; Farzanegan, 2014; Mosikari \& Matiwa, 2014; Dudzeviciute \& Tamosiuniene, 2014):

$$
\begin{aligned}
& y_{t}=\beta_{1,0}+\sum_{i=1}^{p} \beta_{1, i} y_{t-i}+\sum_{j=1}^{p} \beta_{1, p+j} x_{t-j}+\varepsilon_{1 t} \\
& x_{t}=\beta_{2,0}+\sum_{i=1}^{p} \beta_{2, i} y_{t-i}+\sum_{j=1}^{p} \beta_{2, p+j} x_{t-j}+\varepsilon_{1 t}
\end{aligned}
$$

Where: $p$ is the number of lags, $\beta$ - parameter, $\varepsilon$ - error.

If the $p$ parameters $\beta_{1, \mathrm{p}+\mathrm{j}}$ are jointly significant then the null hypothesis that $\mathrm{x}$ does not Granger cause $\mathrm{y}$ can be rejected. Similarly, if the $\mathrm{p}$ parameters $\beta_{2, \mathrm{i}}$ are jointly significant then the null hypothesis that y does not Granger cause $\mathrm{x}$ can be rejected. Granger causality test is based on the concept of causal ordering and assumption as follows: a variable $\mathrm{x}$ is said to Granger cause another variable $\mathrm{y}$ if past values of $x$ help predict the current level of $y$ given all other appropriate information (Stern, 2011; Dudzeviciute \& Tamosiuniene, 2014).

The data have been analyzed using descriptive statistics such as average value, coefficients of correlation. All calculations have been made using Windows-based econometric software Eviews v. 6.0.

\section{The Trends of Defense Spending and Economic Growth}

\section{Statistical Evidence}

Therefore, it is of great importance to investigate whether the relationship between defense spending and economic growth depends on the level of economic development. To that end, the EU countries have been 
grouped into five categories, such as very high economic level, high economic level, upper middle economic level, lower middle and low economic level (Table 1). The level of economic development has been characterized by real GDP per capita ratio. Thereafter, the relationship between defense spending and economic growth among these countries' groups has been examined. Finally, Granger causality test has been applied to detect causality and its direction. Annual data analysis of the EU countries has been carried out in the period of 2004-2013.

According to the level of economic development, the authors have grouped the EU countries into five categories (Table 1).

Table 1

The groups of the $\mathrm{EU}$ countries by the level of economic development

\begin{tabular}{|c|c|c|c|}
\hline Groups of the countries & Real GDP per capita, Euro average & Groups of the countries & Real GDP per capita, Euro average \\
\hline Low economic level & 7.509 & Upper middle economic level & 25.280 \\
\hline Bulgaria & 3.430 & Spain & 20.880 \\
\hline Romania & 4.370 & Italy & 23.910 \\
\hline Latvia & 6.380 & France & 28.750 \\
\hline Lithuania & 7.300 & Germany & 27.580 \\
\hline Poland & 7.560 & High economic level & 33.184 \\
\hline Slovakia & 8.460 & Belgium & 29.520 \\
\hline Croatia & 8.940 & Finland & 30.870 \\
\hline Estonia & 8.660 & United Kingdom & 30.960 \\
\hline Hungary & 8.910 & Austria & 31.240 \\
\hline Czech Republic & 11.080 & Netherlands & 32.680 \\
\hline Lower middle economic & & & \\
\hline level & 15.740 & Sweden & 34.250 \\
\hline Malta & 13.000 & Ireland & 37.900 \\
\hline Portugal & 15.170 & Denmark & 38.050 \\
\hline Slovenia & 14.700 & Very high economic level & 65.444 \\
\hline Greece & 17.497 & Luxembourg & 65.444 \\
\hline Cyprus & 18.340 & & \\
\hline
\end{tabular}

Source: authors' calculations based on Eurostat data 2004-2013 (1)

As table above shows, real GDP per capita varies from EUR 3.4 thou in Bulgaria to EUR 65.4 thou in Luxembourg. Ten the EU member states belong to the group of low economic development. This countries' group distinguishes by lower pace of economic development comparing with other the EU countries. On average, real GDP per capita makes Euro 7.5 thou in this group. Five countries are involved into lower middle group of economic development, where real GDP per capita makes Euro 15.7 thou; four countries belong to the group of upper middle economic level with average GDP per capita Euro 25.3 thou; eight countries represent the group of high economic level with average GDP per capita Euro 33.2 thou. Finally, Luxembourg is the EU member state with very high level of economic development which makes approx. Euro 65.4 thou.

Figure 1 shows the tendencies of real GDP per capita and defense expenditure over the period of 2004-2013.

The global economic and financial crisis has affected the economic development of all the EU countries. In 2009, all the EU countries' groups reported decline in real GDP per capita. The most significant decrease of economy was registered in low economic level countries' group as well as very high economic level group, where real GDP per capita dropped by 8 and 7 percent respectively. The decline of economies of other countries groups made on an average from 5 to 6 percent. In 2013, real GDP per capita has not still achieved pre-crisis level, except the group of the countries with low economic level. The analysis of defense spending as a percentage of GDP shows, that in majority countries the effect of global economic and financial crisis has been noticed from 2010.
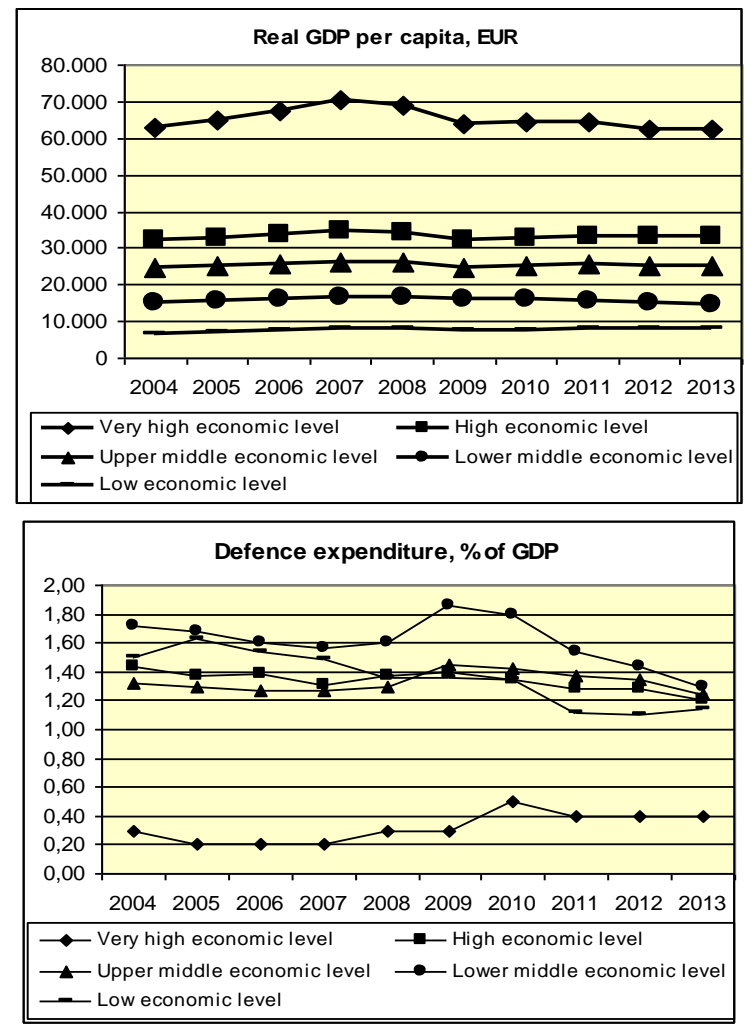

Figure 1. Average real GDP per capita and defense expenditure by countries' group

Source: authors' calculations based on Eurostat data 2004-2013 $(a, b)$. 
Over a period of 2010-2013, the countries of low economic level as well as lower middle level have reported the most significant decrease of defense expenditure as a percentage of GDP. The budgetary motivations for this have been related to less strategic, geopolitical and terrorism related implications.

In order to evaluate the relationship and its direction between defense spending and economic growth correlation analysis has been performed. The results have been summarized in Table 2 .

Table 2

Interrelationship between defense spending and real GDP

\begin{tabular}{|l|c|c|}
\hline \multicolumn{1}{|c|}{ Countries' group } & \multicolumn{2}{c|}{ Relationship strength } \\
\hline Very high economic level & -0.58 & Moderate \\
\hline High economic level & -0.27 & Weak \\
\hline Upper middle economic level & -0.44 & Weak \\
\hline Lower middle economic level & 0.37 & Weak \\
\hline Low economic level & -0.70 & Strong \\
\hline
\end{tabular}

Correlation analysis has shown directions and strengths between defense spending and economic growth variables across the EU countries' groups. It is noticeable that all countries groups, except lower middle, have revealed negative relationships between the variables of economic growth and defense expenditure. This means that as the economies grow in many countries, defense spending decreases and vice versa. On the other hand, it could be interpreted by the security's stability in the European Union countries over the analyzed period. The countries groups with high, upper middle and lower middle level of economic development have demonstrated weak relationships between two indicators while very high and low level of economic development countries have reported moderate and strong interrelationships respectively.

Interrelationships between the trending variables say nothing about causation and simply reflect that both factors have weak, moderate and strong trends relative to the fluctuations around the trend. Correlation does not show causation. In this light, Granger causality testing to modeling the relationship between defense expenditure and economic growth has been applied to this research.

Next section is devoted for this issue.

\section{Granger Causality Testing}

In order to study the forerunner-lag relationship between the two variables such as defense expenditure as a percentage of GDP and real GDP per capita, Granger causality test has been applied in this section. A variable defense expenditure (DE) is said to Granger cause another variable - economic growth (GDP) - if past values of defense expenditure help predict the current level of economic growth given all other appropriate information. This is based on the concept of causal ordering. Similarly, if economic growth in fact causes defense expenditure, then given the past history of economic growth it is likely that information will help predict defense expenditure. Table 3 presents the results of Granger causality test of the EU countries' group according to the economic level of development.

Table 3

Granger causality test results of the EU countries' group

\begin{tabular}{|c|c|c|c|c|}
\hline Null hypothesis & Observations & F-statistic & Probability & Test results \\
\hline \multicolumn{5}{|c|}{ Very high economic level } \\
\hline DE does not Granger cause of GDP & \multirow{2}{*}{9} & 5.49240 & 0.05756 & Rejected \\
\hline GDP does not Granger cause of DE & & 0.01840 & 0.89653 & Accepted \\
\hline \multicolumn{5}{|c|}{ High economic level } \\
\hline DE does not Granger cause of GDP & \multirow{2}{*}{9} & 0.00711 & 0.93556 & Accepted \\
\hline GDP does not Granger cause of DE & & 3.23997 & 0.12195 & Accepted \\
\hline \multicolumn{5}{|c|}{ Upper middle economic level } \\
\hline DE does not Granger cause of GDP & \multirow{2}{*}{9} & 0.39661 & 0.55206 & Accepted \\
\hline GDP does not Granger cause of DE & & 2.18818 & 0.18956 & Accepted \\
\hline \multicolumn{5}{|c|}{ Lower middle economic level } \\
\hline DE does not Granger cause of GDP & \multirow{2}{*}{9} & 0.24542 & 0.63794 & Accepted \\
\hline GDP does not Granger cause of DE & & 4.62940 & 0.07494 & Rejected \\
\hline \multicolumn{5}{|c|}{ Low economic level } \\
\hline DE does not Granger cause of GDP & \multirow{2}{*}{9} & 0.00542 & 0.94371 & Accepted \\
\hline GDP does not Granger cause of DE & & 2.11516 & 0.19608 & Accepted \\
\hline
\end{tabular}

The results of Granger causality test provide new empirical insights into the short - run relationship between defense expenditure and real GDP per capita. The rejection rule is applied, when the probability value is between the level of significance at $5 \%$ and $10 \%$. In general, the research suggests the similar results of all the EU countries' groups, except very high economic level countries' group and lower middle economic level group.
The results of Granger test reveal that the null hypothesis that defense expenditure does not Granger cause of real GDP per capita and real GDP per capita does not Granger cause of defense expenditure cannot be rejected in majority countries. In this light we can conclude, that there is absence of Granger causality between these two variables in high economic level countries, upper middle as well as low economic level countries' group. The case of very 
high economic level group shows the running causality from defense expenditure to real GDP per capita. In contrary, unidirectional causality running from economic growth to defense expenditure has been determined in the case of lower middle level of economic development countries' group, which involves Malta, Portugal, Slovenia, Greece and Cyprus.

Next section summarizes the results of the research and provides the main insights.

\section{Conclusions}

The paper investigates the short-run causal relationship between defense spending and economic growth in the European Union countries. The major limitation of this study has been that it was bounded by defense spending and economic growth only. All other variables have not been considered in this paper. Despite the limitation, we believe that the research highlights key trends and relationships.

Taking into consideration empirical insights from research, it could be concluded that in many cases the defense spending - economic growth nexus has been detected, but the results regarding causality have been different in a range of countries all over the world due to the level of socio-economic development, the period analyzed and the methodology applied.

Correlation analysis is used in order to determine interrelationship between two variables, while Granger causality test is applied in order to suggest which variable in the model has impact on the future value of other variable in the system.

The empirical evidence highlights different results among the EU countries' groups regarding defense spending - economic growth nexus. It is noticeable that all countries groups, except lower middle, have revealed negative relationships between the variables of economic growth and defense expenditure. The countries groups with high, upper middle and lower middle level of economic development have demonstrated weak relationships between two indicators while very high and low level of economic development countries have reported moderate and strong interrelationships respectively.

In terms of causality, there is causal relationship running from defense spending to economic growth in a very high level of economic development country such as Luxembourg (Keynesian macroeconomic approach). In contrary to that, unidirectional causality running from economic growth to defense spending has been determined in the case of lower middle level of economic development countries' group, which involves Malta, Portugal, Slovenia, Greece and Cyprus (Wagnerian macroeconomic approach).

Moreover, the research highlights the absence of Granger causality between variables observed in the case of high level of economic development countries, upper middle as well as low (the approach prevailing in recent studies of different authors).

\section{References}

Alexander, W., \& Robert J. (2015). The Keynesian IS - MR model and military spending. Defense and Peace Economics, 26 (2), 213-221. Available from internet: http://dx.doi.org/10.1080/10242694.2013.857449

Aye, G. C., Balcilar, M., Dunne, J. P., Gupta, R., \& Eyden, R. V. (2014). Military expenditure, economic growth and structural Instability: a case study of South Africa. Defense and Peace Economics, 25 (6), 619-633. Available from internet: http://dx.doi.org/10.1080/10242694.2014.886432. http://dx.doi.org/10.1080/10242694.2014.886432

Alptekin, A., \& Levine, P. (2012). Military expenditure and economic growth: a meta-analysis. European Journal of Political Economy, 28, 636-650. http://dx.doi.org/10.1016/j.ejpoleco.2012.07.002

Anwar, M. A., Rafique, Z., \& Joiya, S. A. (2012). Defense spending-economic growth nexus: a case study of Pakistan. Pakistan Economic and Social Review, 50 (2), 163-182.

Atesoglu, H. S. (2009). Defense spending and aggregate output in the United States. Defense and Peace Economics, 20 (1), 21-26. http://dx.doi.org/10.1080/10242690701775533

Bataineh, I. M. (2012). The impact of government expenditures on economic growth in Jordan. Interdisciplinary Journal of Contemporary Research in Business, 4 (6), 1320-1338.

Chairil, T., Sinaga, D. S., \& Febrianti, A. I. (2013). Relationship between military expenditure and economic growth in ASEAN: evidence from Indonesia. Journal of ASEAN Studies 1(2), 106-121.

Danek, T. (2013). Analysis of relationship between military expenditure and economic growth. The Business and Management Review, 3(3), 51-57.

Dimitraki, O., \& Ali, F. M. (2013). The long-run causal relationship between military expenditure and economic growth in China: revisited. Defense and Peace Economics, 24, 1-16. Available from internet: http://dx.doi.org/10.1080/ 10242694.2013.810024.

Dudzeviciute, G., \& Tamosiuniene, R. (2014). Energy consumption and economic growth nexus in the Baltic countries: causality approach. KSI Transactions on Knowledge Society 7(4), 12-172.

Duella, A. (2014). Military burden and economic growth: evidence from a multivariate cointegration analysis. Journal of Global Economics, 2(3), 119. doi:10.4172/economics.1000119. 
Dunne, J. P., \& Tian, N. (2015. Military expenditure, economic growth and heterogeneity. Defense and Peace Economics, 26 (1), 15-31. Available from internet: http://dx.doi.org/10.1080/10242694.2013.848575

Dunne, J. P., \& Nikolaidou, E. (2012). Defense spending and economic growth in the EU15. Defense and Peace Economics, 23(6), 537-548. http://dx.doi.org/10.1080/10242694.2012.663575

Eurostat database on economic growth indicators. (2012 a). Available from internet: http://appsso.eurostat.ec.europa.eu /nui/show.do?dataset=nama_aux_gph\&lang=en.

Eurostat database on general government expenditure. (2012 b). Available from internet: http://ec.europa.eu/eurostat/ data/database.

Farzanegan, M. R. (2014). Military spending and economic growth: the case of Iran. Defense and Peace Economics, 25 (3), 247-269. http://dx.doi.org/10.1080/10242694.2012.723160

Feridun, M., Sawhney, B., \& Shahbaz, M. (2011). The impact of military spending on economic growth: the case of North Cyprus. Defense and Peace Economics, 22 (5), 555-562. http://dx.doi.org/10.1080/10242694.2011.562370

Hartley, K., \& Sandler, T. (2011). The Economics of Defense Spending. Routledge: London and New York. p. 285.

Hirnissa, M. T., \& Baharom, A. H. (2009). Military expenditure and economic growth in Asean-5 countries. Journal of Sustainable Development, 2 (2), 192-202. http://dx.doi.org/10.5539/jsd.v2n2p192

Keller, K., Poutvaara, P., \& Wagener, A. (2008). Military draft and economic growth in OECD countries. Helsinki Center of Economic Research. Discussion Pater, No 228. p. 40.

Khalid, M. A., \& Mustapha, A. B. (2014). Long-run relationship and causality tests between military expenditure and economic growth in India. The Economics and Finance Letters, 1(6), 49-58. http://dx.doi.org/10.18488/journal.29/ 2014.1.4/29.4.49.58

Kollias, C., \& Paleologou, S. (2010). Growth, investment and military expenditure in the European Union-15. Journal of Economic Studies, 37(2), 228-240. http://dx.doi.org/10.1108/01443581011043618

Lilico, A. (2013). Why defense spending can help to promote longer - term growth. Available from internet: http://www.telegraph.co.uk/finance/comment/10083015/Why-defense-spending-can-help-to-promote-longer-termgrowth.html.

Malizard, J. (2014). Defense spending and unemployment in France. Defense and Peace Economics, 25 (6), $635-642$. Available on the Internet: http://dx.doi.org/10.1080/10242694.2013.857450

Mosikari, T. J., \& Matiwa, K. (2014). An analysis of defense expenditure and economic growth in South Africa. Mediterranean Journal of Social Sciences, 5 (20), 2769-2776.

Mylonidis, N. (2008). Revisiting the nexus between military spending and growth in the European Union. Defense and Peace Economics, 19(4), 265-272. http://dx.doi.org/10.1080/10242690802164801

Pradhan, R. P. (2010. Modelling the nexus between defense spending and economic growth in Asean- 5: evidence from cointegrated panel analysis. African Journal of Political Science and International Relations, 4(8), 297-307.

Rashid, A. K. M., Saifur, \& Arif, Md. Zahir Uddlin. (2012). Does military expenditure influence economic growth in developing countries? A cointegration analysis. Journal of Arts, Science and Commerce, 3(1), 92-99.

Shahbaz, M., Afza,T., \& Shabbir, M. S. (2013). Does defense spending impede economic growth? Cointegration and causality analysis for Pakistan. Defense and Peace Economics, 24 (2), 105-120. http://dx.doi.org/10.1080/10242694. 2012.723159

Savolskis, D. (2014). Gynyba ir ekonomika [Defense and economics]. Available on the Internet: http://www.delfi.lt/news/ ringas/ politics/ d-savolskis-gynyba-ir-ekonomika.d?id=66525176.

Stern, D. I. (2011). From correlation to Granger causality. Crawford School Research Paper, No 13 , 37 p. http://dx.doi.org/10.2139/ssrn.1959624

Tiwari, A. K., \& Shahbaz, M. (2013). Does defense spending stimulate economic growth in India? A revisit. Defense and Peace Economics, 24 (4), 371-395. http://dx.doi.org/10.1080/10242694.2012.710814

Topcu, M., \& Aras, I. (2015). Defense spending and economic growth: extended empirical analysis of the European Union countries. Defense and Peace Economics, 26 (2), 233-246. http://dx.doi.org/10.1080/10242694.2013.774771

Yang, A. J., Trumbull, W. N., Yang, C. W., \& Huang, B. N. (2011). On the Relationship Between Military Expenditure, Threat, and Economic Growth: A Nonlinear Approach. Defence and Peace Economics, 22(4), $449-457$. http://dx.doi.org/10.1080/10242694.2010.497723

The article has been reviewed. Received in April, 2015; accepted in June, 2016. 